\title{
Participating in a Blog: Jordanian EFL Learners' Voices
}

\author{
Nafiseh Zarei $^{1} \&$ Yasser Al-Shboul ${ }^{2}$ \\ ${ }^{1}$ School of Language Studies and Linguistics. FSSK, Universiti Kebangsaan Malaysia \\ ${ }^{2}$ School of Language Studies and Linguistics. FSSK, Universiti Kebangsaan Malaysia
}

Correspondence: Nafiseh Zarei, 33B.22.01. Villa Putra condominium. Jalan Tun Ismail. 50480. Kuala Lumpur. Tel: 60-1-7310-2551. E-mail: Nafiseh_zarei@yahoo.com

Received: November 4, 2013

Accepted: November 17, 2013

Online Published: November 20, 2013

doi:10.5430/elr.v2n2p53

URL: http://dx.doi.org/10.5430/elr.v2n2p53

\begin{abstract}
This study investigates the Jordanian EFL learners' perceptions towards language learning through blog. It seeks to assess the usefulness of blogging in enhancing learners' English language skills. The participants of the present study included 10 post graduate Jordanian EFL Learners who attended English Intensive Course. Data were collected through semi-structured interview questions regarding learners' feedback on their perceptions to the integrated blog. The data obtained from the semi-structured interview was recorded, transcribed and described by the researchers and finally analyzed qualitatively. The findings of the study revealed that the learners perceived the blog as an interesting and helpful learning tool since interacting via blog helped them improve their English language skills as well as their peer feedback. Hence, the blog played an important role for the Jordanian EFL learners as it allowed them to exchange their experiences and thoughts with peers. The study concluded that integration of social networks, such as blogs into Jordanian EFL learners' classes could enhance their English language learning processes.
\end{abstract}

Keywords: Foreign language learning, Perception, Blogging, Social interaction

\section{Introduction}

Technology has created opportunities for learners to build up their knowledge and get possible supports to share their understanding and experiences in various ways in order to enhance language learning. Nowadays; language learning is expanded outside the classroom where learners can learn the language without teacher's help. There is a variety of different social networks where learners can learn the language independently and improve their learning on their own. The integration of social networks, such as blogs, Facebooks, twitters, discussion forums, emails, wikis and etcetera into language classes may help to facilitate the language learning and language acquisition processes by allowing learners to take part in the learning process. The learners can explore and reflect upon their learning, as well as interact with peers, teachers and content (Castaneda et al., 2011). Blogs as one type of the social networks give the learners the chance of being independent learners. Learners can use blogs at anytime and anywhere in order to practice the language skills. Additionally, blogs are a kind of tools which are easy accessible for learners as well as teachers. They can play an essential role in both language teaching and language learning.

There are studies which have been carried out on the use of blog as an educational device in various contexts (Pinkman, 2005; Seitzinger, 2006; Song \& Chan, 2008; Sun, 2009; Supyan et al., 2009; Supyan, 2011). These studies have contributed to a better understanding of advantages and disadvantages of using blogs in education. There are also some studies which have been conducted in the area of using computer as an educational tool among Jordanian EFL contexts such as: Mahfouz and Ihmeideh (2009), Al Omari (2009), Al-Abed Al-Haq and Al-Sobh (2010), and Al Masri (2011), however, according to the researchers' best knowledge, no specific study has been carried out on Jordanian EFL learners' perceptions towards language learning process using blog. Therefore, the present study seeks to investigate the Jordanian EFL learners' perceptions towards language learning using blog as a platform. This is the gap where the contribution will be made by the current study.

\section{Related studies}

Many studies have been conducted on the utilizing blog as an educational tool from various perspectives. For instance, Hong et al. (2003) conducted a study among Malaysian learners on the success of a technology and internet-enriched teaching and learning environment in molding positive attitudes. Data collected via questionnaires. 
The participants included 88 second-year undergraduate students who were randomly selected from different 5 faculties at Universiti Malaysia Sarawak (UNIMAS). The findings of the study showed that the learners had positive attitudes towards using the Internet as a learning tool, adequate basic knowledge of the Internet, and illustrated the learning environment as supportive of using the Internet for learning. So, this study is significant as it focused on both teaching and learning aspects. However, this study merely looked at students' attitudes towards using the Internet as a learning device. Hence, the current study is focusing on the learners' perceptions towards language learning through blog.

Kuzu (2007) examined the impact of course blog on supporting instruction and sustaining social interaction using semi-structured interview as an instrument. The sample of the study included 30 students of the Department of Computer Education and Instructional Technologies at Anadolu University in Turkey. The findings of the study showed positive results regarding the pre-service teachers' views on instructional use of blog. Moreover, the results revealed that blog use empowered their social interaction with their peers as well as the course instructor. The present study is related to Kuzu's study in terms of the instrument for data collection as both used semi-structured interview questions. While Kuzu focused on the learners' social interaction in the blog environment, the current study focuses on learners' perceptions towards language learning using blog.

Another study was conducted among Malaysian learners by Supyan (2011) who explored the role of blogs in a teacher training program among Malaysian post graduate students, who were pre-service and in-service teachers. A survey questionnaire was used for the purpose of data collection. The researcher used purposive sampling consisted of 28 students. The results of the study indicated that blogs could enhance learners' positive attitudes. Unlike the present study which focuses on learning aspects, Supyan' study focused on teaching aspects. Moreover, he focused on students' attitudes regarding participation and discussion in the blog while the current study investigates the students' perceptions regarding language learning process using blog.

Nepomuceno (2011) investigated how blogging can be used as an alternative activity in tertiary writing classes among Filipino students. The focus of the study was on academic writing skills. Data were collected through a survey. The subjects of the study included 79 Sophomore College students enrolled in academic writing course. The findings of the study displayed that integrating blog as a tool in academic writing class motivated the students. The focus of this study was on teaching aspects and writing skill, however the present study focuses on the process of learning by considering the four English language skills.

In Arabic context, Al-Fadda and Al-Yahya (2010) investigated a study on the students' experiments of using blogs to encourage themselves to do pre-class reading assignment and reflections after class. The participants were 95 students who were in two different majors. The majority of them were undergraduate Information Technology students and only five of them were ESL graduate students. Data collection was carried out via a survey. The findings of the study showed that there was a positive attitude towards the use of blogs for pre-class preparation and post-class reflections. Yet, considering the successful experience, it is vital to consider the size of the sample, students' educational levels, and the type of reading assignments as well.

Fageeh (2011) conducted an experimental study on the use of blog and its effects on developing positive attitudes towards writing skill among EFL learners. Data were collected using the triangulation method via questionnaire, pre-test, post-test and students' blogs and assignments. The participants were 50 students who were belonged to the English Department.The results of the study showed that the students found the blog as an opportunity for self-expression in English, writing for both a local and global audience, creating active, interactive social exchanges in blogs, and maintaining an interactive relationship with a real time readership. In general, students had shown positive attitudes towards the use of blog. The study concluded that blogs can create learning motivation environment and opportunities for authorship and readership. This study is significant because it used the triangulation method for data collection. It is worth stating that this study examined students' attitudes towards writing skill using blog, whereas the current study is an investigation of learners' perceptions towards language learning using blog.

Aljumah (2012) investigated students' attitudes and perceptions towards blog in writing skill and he also focused on the pros and cons of using blog in language learning. The subjects of the study involved 35 Saudi students majoring in English. Data were collected via questionnaires within one semester. The results of the study revealed that students had positive perceptions towards weblog use in their writing classroom. Moreover, the findings demonstrated that learner-perceived advantages of using weblog included increased interest and motivation to use English due to interaction with peers. It is worth noting that Aljumah's study focused on learners' perceptions as well as their attitudes towards weblog in writing skill. As is the case with Fageeh's study (2011), Aljumah's study (2012) 
also focused on English writing skill. The present study extends the scope of this research to include not only writing skill but also other skills in English language (Reading, Speaking and Listening).

Alhojailan, (2012) examined the current use and effectiveness of Weblog services in higher education. The focus of his study was to refine the questionnaires and the interviews so that he would gain the experience and avoid error prior to commencing the empirical study. The samples included 28 students who were from Saudi Arabia. The researcher used qualitative method and collected the data via questionnaires and interviews. The results of the study revealed that the participants were varied in two different groups. The participants of the first group stated that using blogs with did not provide the interest that they were expecting. However, the participants of the other group agreed that they had uncertain opinions whether or not the blogs had the potential to improve their learning experiences nevertheless they were very satisfied regarding the use of the blogs.

In another study, Sad (2013) examined the role of blog on students' motivation in Palestine context. The participants of the study included 22 male students in grade 11 in East Jerusalem during the period of one semester. Data were collected using observation, content analysis and interviews with teachers as well as the students. The findings of the study showed positive correlation between student blogging and student motivation, but there was much significant consideration for the setting since low-achieving students were different, like type of assignment used, authenticity of assessment, and teacher efficacy. This study is important because it is one of a very small number of Arabic blog studies that examined the role of blog on students' motivation in Palestine context, thus it would make a valuable contribution to the literature. Similar to Fageeh's (2011) study, this study also used the triangulation method for data collection.

In Jordan context, Al-Abed Al-Haq and Al-Sobh (2010) explored a quantitative study on the effectiveness of a web-based writing instructional EFL program among 122 Jordanian secondary students in two male schools and two female ones. Data were collected through a pre-post achievement test. The findings of the study showed statistically significant differences $(\alpha=0.05)$ in the students' mean scores of the overall English writing achievement post-test in favour of the experimental group. Moreover, there was a significant difference $(\alpha=0.05)$ among the mean scores of the students' achievement post-test for the discoursal component "content" in favour of the experimental group. In terms of gender, females showed favour with statistically significant differences $(\alpha=0.05)$ as compared to males.

Al Masri (2011) examined the effect of using web-based curricula in English language among Jordanian school students. Data were collected using pre/post test within 8 weeks with regard to English language grammar. The participants of the study were 321 eighth grade students; 156 male students and 165 female ones. The results of the study indicated that there were statistically significant differences in the post-test between the control and the experimental groups regarding the experimental group, and there was no statistically significant difference in the students' achievements in terms of gender. There was also no statistically significant difference regarding the interaction between gender and group.

Finally, Abu Naba'h (2012) investigated the impact of using computer assisted grammar teaching on the performance of Jordanian EFL students. The subjects of the study included 212 secondary school students divided into four experimental groups and four control groups. Data were collected using pre-post test to find out the impact of the software program on students' achievement in grammar. The test consisted of 30 multiple-choice items of four alternatives. The results of the study showed that there were statistically significant differences $(\alpha<0.05)$ between the pupils' achievement mean scores in grammar in favour of the students in the experimental group which is mainly attributed to the instructional method of teaching. In addition, there were statistically significant differences $(\alpha<0.05)$ between the pupils' achievement mean scores in grammar in favour of the scientific stream students due to stream of study. Based on these results, the researcher recommended that English language teachers to use computer assisted instruction in their teaching. Unlike the present study, none of the mentioned studies in Jordan context focused on the learners' perceptions towards language learning process. As it is obvious the researchers merely focused on the effectiveness of web-based curricula, writing skill or grammar among Jordanian EFL learners. Hence none of those studies used blog as an educational tool to be used by the learners. It is worth mentioning that the focuses of the studies among Jordanians were mostly on teaching aspects rather than learning. Moreover, using interview as an instrument for data collection has been virtually absent in those studies. Thus the present study used a semi-structured interview to elicit perception data from the learners.

To sum up, the above studies examined web based tools in various contexts such as: Malaysia, Turkey, Philippines, Saudi, Palestine and Jordan. Those studies used different instruments for data collection such as questionnaires (Hong et al., 2003; Al-Fadda \& Al-Yahya, 2010; Fageeh, 2011; Supyan, 2011; Nepomuceno 2011; Aljumah, 2012; Alhojailan, 2012), semi-structured interviews (Kuzu, 2007; Alhojailan, 2012; Sad 2013), observation content 
analysis (Sad, 2013), and pre-post tests (Al-Abed Al-Haq \& Al-Sobh, 2010; Al Masri, 2011; Fageeh, 2011; Abu Naba'h, 2012). It is important to state that none of the above studies focused on learners' perceptions towards language learning. Accordingly, the present study aims to investigate the Jordanian EFL learners' perceptions towards language learning process through blog. This is the main contribution made by the current study.

\section{The study}

This study attempts to investigate the Jordanian EFL learners' perceptions towards language learning through blog. According to Campbell (2004) "using blogs helps students in navigating the English websites and it improves students' knowledge and information on English language via exchanging their opinions while interaction". The present study is based on Vygotsky's social constructivist theory (1978). Vygotsky's idea of constructivism states that learning will become more meaningful when learners could interact with each other socially in a given environment. Social interaction would take place among the learners while participating in the blog environment in order to share their views and experiences. For the purpose of the current study the blog was designed for a group of post graduate Jordanian EFL Learners. The English language learning lessons and exercises which were related to the objectives of the course were prepared in the blog. The learners were able to access the language learning materials in the blog and make use of them. They were given chances to use the language learning materials as well as sharing opinions and knowledge with peers in the blog. They were also able to discuss the lessons taught by the teacher in the classroom with their classmates in the blog environment. Leaving comments to exchange ideas and views by the learners would lead them to interact with each other in the blog environment. In other words, the learners were able to participate in the blog discussion to share their ideas, experiences and knowledge. Moreover, they had the opportunity to utilize the English language lessons and exercises in order to improve their English language skills. Therefore, the related research question emerged from the literature is what the Jordanian EFL learners' perceptions are towards language learning process through blog.

\section{Method}

The objective of the current study is to investigate the Jordanian EFL Learners' perceptions towards language learning through blog. This study employed the qualitative method approach by collecting data using semi-structured interview.

\subsection{Participants}

The present case study used purposive sampling. The samples included 10 post graduate Jordanian EFL Learners who attended English Intensive Course for one semester at Universiti Utara Malaysia (henceforth, UUM). The international candidates by coursework who would like to pursue their education with UUM, but did not have TOEFL (Test of English as a Foreign Language) or IELTS (International English language Testing System) or even they were unable to get the required TOEFL/IELTS scores, should take the English Language Placement Test (ELPT) conducted by the university. If the candidates failed the ELPT, they would attend that course which was designed especially for those who did not demonstrate an acceptable level of English proficiency.

\subsection{Instrument and procedure}

The semi-structured interview questions were conducted to evaluate the learners' perceptions towards the English language learning in the blog. The questions were pilot-tested on a group of students as well as giving them to two experts to check the validity and reliability. The two experts confirmed the questions to be used as the instrument to run this study. The researchers improved some of the questions of the interview according to the learners' feedback after the pilot study. The final version of the semi-structured interview questions used for the purpose of data collection of this study. The researchers interviewed all of the learners using a discussion room in the library. The data obtained from the semi-structured interview was recorded, transcribed and described by the researchers and finally analyzed qualitatively.

\section{Findings and discussion}

The purpose of this study is to investigate the Jordanian EFL learners' perceptions towards language learning through blog. The data was compiled and analyzed based on the objective of the study. The researchers interviewed 10 Jordanian EFL learners. The first question in the interview was set to find out their perceptions regarding the language learning materials in the blog. The majority of the learners $(n=8)$ stated that the language learning materials in the blog were helpful and advantageous for them because they could improve their writing skills and conversation capabilities through expanding their English vocabularies and grammar. For example, one of the interviewees mentioned that: 
"Actually, the blog was very good for me; I learned many things from the blog. For example, I learned a lot of new vocabularies and saw how my friends wrote correctly in English. I also liked the videos you posted in the blog and I always listened to them. I learned many grammar structures also and learned how to come up with a better writing for my assignments."

On the other hand, only two of the learners believed that they could learn from the teacher in the classroom, thus they found that learning through the blog materials was not that much necessary for them. For example one of them stated:

"To me, I can learn from my teacher in the class which is enough for me. There is no need to use the blog."

The second question was formulated to find out which language learning materials were the most useful ones in the blog. 5 learners mentioned that the sections dealt with writing skill and grammar structures were the most useful language materials posted in the blog. However, 3 out of 10 learners believed that English vocabulary, speaking skill and grammar exercises were significantly beneficial for them. 6 of the learners believed that all of the language learning materials benefited them and help them improve their English skills. They emphasised that by using the English language lessons and exercises they developed their course assignments as well. For instance, one learner stated that:

"In my idea, having the blog gives a good opportunity to me to learn more and more. Especially regarding my writing, grammar, listening and speaking skills. I always got help from the blog to do my assignments before I submitted to my teacher. Everything in the blog was really useful. Without that blog I had to surf Google looking for needed information which was hard and time consuming for me. Even in Google, it is sometimes hard to find the language materials and lessons that I really need to learn for my English. Therefore, I always made use of the language learning materials in the blog as they were all provided and organized very well."

The third question of the interview was made to know which language learning materials were unnecessary for the learners to use in the blog. Based on the learners' respondents, the researchers found out that none of the lessons, videos, audios and exercises provided in the blog was unnecessary. According to the learners' feedback by using different types of English language lessons and learning different aspects of English skills they will be able to enhance their English language. In other words, none of the English skills can be separable in order to master English language. For example one of the learners mentioned:

"For me, I found all the language learning materials provided in the blog useful. I could learn from all of them and I think they were very important. If we read different structures, idioms, vocabularies and language learning tips and techniques about English language in the blog, we can always improve our English language."

The fourth question was formulated to find out the learners' feelings after using the language learning materials in the blog. 6 of the learners voiced out that reading the English lessons in the blog made them feel more confident about their English. They believed that the feeling of the self-confidence helped them be more interested in learning English as well as attending the English Intensive Course. In other words, feeling more confident led them to learn more and being active participants in the classroom. One learner stated that:

"Whenever I used the blog to learn something I always felt good and happy because I did not see my teacher to become stressful. I could learn in very good and relaxing environments like my room or any other places but not the classroom. So I never got stressed. In the class sometimes I am shy to talk or participate in the class discussion. Sometimes I feel uncomfortable to learn because the classroom, classmates and teacher make me feel stressed. I am really happy to write something in the blog and comment on my friends' posts and improve my learning."

In addition, 3 learners stated that unlike learning in the classroom, they felt relaxed during the learning process. They agreed that learning in the classroom sometimes creates stress and an uncomfortable environment to learn. That happens due to the time and space constraint. However, learning through the blog was an easy way in which the learners could read and learn at any time and any place they were ready to be involved in the learning process. Moreover, 2 learners mentioned that learning outside the classroom gave them the feeling of satisfaction and independence as learners. They emphasized that learning independently was a good opportunity for them to learn on their own and improve their English skills. 
The next question was made in order to understand if the learners learned more since using the blog or not. Based on the learners' responses, the researchers came to the conclusion that the learners could become familiar with a lot of aspects in English language by integrating the blog to their English Intensive class. The learners mentioned that there were a lot of new knowledge and information that they acquired and learned through the language learning materials in the blog. According to their feedback, although the teacher taught some English lessons in the classroom, however the learners learned many extra English grammar, vocabularies and skills which were not mentioned by the teacher in the classroom. All in all, the learners were satisfied that they learned more via using the blog as an English language learning platform. For example one learner stated:

"Of course I learned more. I could use the English language materials at any time and refer to the grammar lessons when I needed them. So unlike the class which was only for two hours, the blog could provide learning process at anytime with no boundary. So I learned a lot via using the blog and I think if I did not use it, I would not learn this much. We can learn in the classroom but not everything in detail; however in the blog we can learn almost everything. I want to say that by using the blog I really learned more."

The last question was set to investigate if the learners faced any difficulties while using the language learning materials in the blog. The majority of the learners stated that they did not have any problems to access and read the English language learning materials in the blog. However, merely 2 learners mentioned that having slow internet connection sometimes affected their language learning processes.

"I think those students who could use computer and internet were able to use the blog which is very easy and simple. So I did not have any problems whenever I used the blog. It was always easy and interesting."

Based on the findings of the present study, the researchers would like to emphasize that integrating blog in EFL classrooms would benefit the learners to enhance their processes of language learning. In other words, it can be suggested that integrating social networks in English language classes in Jordan context, could contribute to teaching and learning processes. Hence, the traditional way of teaching and learning English language should not be the only focus for the teachers and learners. It is worth mentioning that, the social interaction which takes place in the discussion forum of the blog is beneficial for the learners to learn new knowledge and information from their peers as well as increasing their critical thinking.

\section{Conclusion}

In conclusion, the results of the present study indicated that the Jordanian EFL learners were satisfied about using the language learning materials in the blog to enhance their English language. The blog provided them the much needed communication and discussion outside the classroom environment. The learners perceived the blog as an interesting and helpful learning tool since interacting via blog helped them improve their English language skills as well as their peer feedback. Hence, the blog played a significant role for the Jordanian EFL learners as it allowed them to share their experiences, information, knowledge and thoughts with peers. Learning English language via the blog could facilitate their processes of learning. Making blog available in the context of this study could motivate the Jordanian EFL learners to participate not only in the blog discussion but also the class activities.

\section{References}

Al-Abed Al-Haq, F. \& Al-Sobh, M. (2010). The effect of a web-based writing instructional EFL program on enhancing the performance of Jordanian secondary students. Jaltcalljournal, 6 (3), 189-218.

Al-Fadda, H. Al.-Yahya, M. (2010). Using web blogs as a tool to encourage pre-class reading, post-class reflections and collaboration in higher education. US-China Education Review, 7 (7), 100-106.

Aljumah, H. F. (2012). Saudi Learner Perceptions and Attitudes towards the Use of Blogs in Teaching English Writing Course for EFL Majors at Qassim University. English Language Teaching, 5 (1), 100-116.

Alhojailan, M. (2012). The current use and effectiveness of Weblogs as e-learning tools in higher education. 3rd International Conference on e-Education, e-Business, e-Management and e-Learning, Singapore, IACSIT Press. [Online] Available: http://www.ipedr.com/vol27/23-IC4E\%202012-F00031.pdf

Al Masri, A. (2011). The Impact of Using Web- Based Curricula on Jordanian Schools Students' Achievement in English Language. Barcelona European Academic Conference. [Online] Available: http://conferences.cluteonline.com/index.php/IAC/2011SP/paper/viewFile/476/482 
Alomari, A. (2009). Investigating online learning environments in a web-based math course in Jordan. International Journal of Education and Development using ICT, 5 (3), 19-36.

Campbell, A. P. (2004). Using live journal for authentic communication in EFL classes. The Internet TESL Journal, 10 (9), 51-62.

Castaneda, D., Ahern, T., \& Díaz, S. (2011). Teaching and learning the Spanish aspect using blogs and wikis: An exploratory study. IALLT Journal of Language Learning Technologies, 41 (1), 64-89.

Fageeh, A., I. (2011). EFL Learners' Use of Blogging for Developing Writing Skills and Enhancing Attitudes Towards English Learning. Journal of Language and Literature, 2 (1), 31-48.

Hong, K.-S., Ridzuan, A. A., \& Kuek, M.-K. (2003). Students' attitudes toward the use of the Internet for learning: A study at a university in Malaysia. Educational Technology \& Society, 6 (2), 45-49.

Kuzu, A. (2007).Views of pre-service teachers on blog use for instruction and social interaction. Turkish Online Journal of Distance Education-TOJDE, 8 (3), 34-51.

Mahfouz, S. \& Ihmeideh, F. (2009). Attitudes of Jordanian university students towards using online chat discourse with native speakers of English for improving their language proficiency. Computer-Assisted Language Learning, 22 (3), 207-227. http://dx.doi.org/10.1080/09588220902920151

Abu Naba'h, A. M. (2012). The impact of computer assisted grammar teaching on EFL pupils' performance in Jordan. International Journal of Education and Development using Information and Communication Technology, 8 (1), 71-90.

Nepomuceno, M. (2011). Writing Online: Using Blogs as an Alternative Writing Activity in Tertiary ESL Classes. TESOL Journal, 5. 92-105.

Pinkman, K. (2005). Using Blogs in the Foreign Language Classroom: Encouraging Learner Independence. The JALT CALL Journal 1(1), 12-24.

Sad., A. (2013). Motivating low-performing 11th graders through blogging: A case study. International Journal of Instructional Technology and Distance Learning 9 (12), 17-30.

Seitzinger, J. (2006). Be Constructive: Blogs, Podcast, and Wikis as Constructivist learning Tools. Learning Solutions. e-magazine.7. [Online] Available: http://www3.griffith.edu.au/03/ltn/docs/Design_Strategies.pdf

Song, H. \& Chan, Y. (2008). Educational blogging: A Malaysian university students' perception and experience. Proceedings ascilite Melbourne, 954-963. [Online] Available: http://www.ascilite.org.au/conferences/melbourne08/procs/song.pdf

Sun, Y. (2009). Voice Blog: An Exploratory Study of Language Learning. Language Learning \& Technology 13(2), 88-103.

Supyan, H., Norizan, A., R. \& Dalia, S. Q. (2009). Developing Blogs: New dimension in language teacher education. Paper presented Teaching and Learning of English in Asia (TLEiA Three), Orchid Garden Hotel. Brunei Darussalam. [Online] Available: http://maele.net/papers/2009\%20developing\%20blogs\%20TEIFL\%20brunei\%20supyan\%20norizan\%20dalia.p df

Supyan, H. (2011). Using blog to enhance process writing approach: Is there anything new? SoLLs. INTEC.11 International Conference. Language, Culture, \& Literacy: Engaging Diversity in Challenging Times, Hotel Equatorial Bangi, Selangor. [Online] Available: http://supyanhussin.files.wordpress.com/2011/05/sollsintec-2011-supyan1.pdf

Vygotsky, L. L. S. (1978). Mind in Society: The Development of Higher Psychological Processes. Cambridge: Harvard University Press. 